\title{
THE FUNCTIONS OF IDIOMS WITH MAGICAL TERMINOLOGY IN BUILDING THE STORY OF J. K. ROWLING'S “HARRY POTTER AND THE ORDER OF THE PHOENIX”
}

\author{
Haris Fadhillah ${ }^{1)}$, J Bismoko ${ }^{2)}$ \\ Universitas Lambung Mangkurat ${ }^{1)}$, Sanata Dharma University ${ }^{2)}$ \\ manusiasuper@gmail.com ${ }^{1)}$, bismokj@yahoo.com ${ }^{2)}$
}

\begin{abstract}
This study describes the functions of idioms with magical terminology in Harry Potter and the Order of the Phoenix in building the story. This study analyzed the novel from the linguistics perspective. The idioms with magical terminology found in the novel were compared to real English idioms. Comparison was done word by word and also to the context of the story. The analysis was also done by comparing words' meaning and the semantic features. Finally the data were analyzed with related theories of linguistics and discourse analysis. The results of this study can be used as a consideration in teaching cultural relevancy in language teaching from the linguistic point of view in a novel.
\end{abstract}

Keywords: functions of idioms, Harry Potter and the Order of the Phoenix, cultural relevancy in language teaching

\begin{abstract}
Abstrak
Penelitian ini mendeskripsikan fungsi-fungsi idiom dengan istilah khusus dunia sihir dalam membangun cerita pada novel Harry Potter and the Order of the Phoenix karangan J.K. Rowling dengan menganalisa novel dari sudut pandang teori linguistik. Idiom pada novel dibandingkan dengan idiom asli dalam bahasa Inggris. Perbandingan dilakukan kata perkata dan juga dengan konteks sesuai alur cerita novel. Selain itu, analisa dilakukan dengan membandingkan makna kata dan fitur semantik yang menyertainya. Analisa juga dilakukan dengan menggunakan teori-teori Linguistik serta Analisis Wacana.Hasil penelitian ini diharapkan dapat dijadikan bahan pertimbangan pengajaran unsur budaya dalam bahasa dari sudut pandang linguistik pada sebuah novel.
\end{abstract}

Kata kunci: fungsi idiom, Harry Potter and The Order of the Phoenix, pengajaran unsur budaya dalam bahasa. 


\section{INTRODUCTION}

The world has been shocked by Harry Potter phenomenon, a gorgeous fiction story book series written by British J. K. Rowling. Harry Potter is a story about a magic world, the separated hiding world from the human world. There are so many reasons of why this story becomes so popular. Rowling has successfully established an imaginative magic world in her idea and translated it into a well-written story. Harry Potter's superiority is an unlimited vocabulary of Rowling's and the great story line.

Harry Potter is a story for children. Yet, adults also like it because they feel excited with the plot. The success of this best-selling British fantasy series has generated an unprecedented level of excitement in both children and adults. The Harry Potter books become best sellers before they are written and/or released. According to BBC News data base, as of June 2011, the book series has sold about 450 million copies, making it the best-selling books series in history and has been translated into 67 languages.

The massive spread of Harry Potter challenges the researchers and educators to find the ways about using the novel as a medium of teaching. Some schools in US teach about British Culture by using Harry Potter story. The other have created a special lesson plan for the four skills; reading, speaking, writing, and listening by the only use of Harry Potter Novel as the main media. Some characterizations in Harry Potter are also put as a topic of discussion about feminism, gender issue, politics in England, etc.

Harry Potter is full of cultural symbols, linguistic forms, and literary values. Many things can be studied from Harry Potter. Since nowadays students do not read such a thing like Tom Sawyer's or Shakespeare's work, a popular novel that is full of linguistics feature can help them to learn more about English language.

\section{Idioms}

One of the things that can be studied from Harry Potter is its idiomatic expression. The idiom is the highest level of language creativity. Learning the idioms of another language requires strong effort and good media. Idioms, as linguistic idiosyncrasy, present some of the most difficult materials for learners of English as a foreign or second language to successfully understand. The difficulties in understanding idioms arise from two different characteristics of language. The meaning of many idioms often does not correspond to idiom's individual components.

Idiom, as one of the language components, is defined as an expression having a certain meaning. It consists of at least two words. This combination of words called as an idiom cannot be understood based on the words in isolation (Fromkins, Roadman and Hyams, 2011, pp.150-152). For instance, an idiom give up means stop, although it consists of give and up, each of which has its own lexical meaning.

Idiom is an expression whose meaning cannot be predicted from the usual meanings of its constituent elements. Ammer (1997, p.2) defines idiom as a set phrase of two or more words that means something different from the literal meaning of the individual words. Idioms are the idiosyncrasies of a language. Often defying the rules of logic, they pose great difficulties for non-native speakers. Indeed, the true test of an idiom is whether it changes meaning when rendered word for word in another language

Idiom is a traditional way of saying something. Often it does not seem to make sense if it is taken literally. Someone who is unfamiliar with English idioms would probably not understand an idiom and make mistake in getting its actual meaning. He tends to understand it based on the meaning of word by word.

Idioms, grammatically as well as semantically, have special characteristics. They must be entered into the lexicon or mental dictionary as single items with their meanings specified, and speakers must learn the special restrictions on their use in sentences.

All languages have idioms, but idioms rarely if ever translate word for word from one language to another. In the case of English, a typical commercial idiom dictionary such as English Idioms-Sayings \& Slang by Wayne Magnuson (2003) lists about 4,000. The American Heritage: Dictionary Of Idioms by Christine Ammer (1997) has almost 10,000 English idioms and its meanings. The oldest idioms dictionary used in this research is written by James Main Dixon entitled Dictionary of Idiomatic English Phrases which was published in 1891 . The most commonly use idioms dictionary in this research is Oxford Dictionary of Idioms edited by Judith Siefring (2004). It contains about 6000 idioms and the meanings. Clarke (2010, p.7) estimated there are about 15,000 English idioms and 5,500 of it are in regular use. 
Most idioms originate as metaphorical expressions that establish themselves in the language and become frozen in their form and meaning. Idiom is a phrase or word used in a special meaning that you can not understand from just knowing the dictionary definition and the grammar of the parts.

There are many definitions about idiom, but still occur some similarity. Idiom is a language expression, it formed by words and the meaning cannot be defined from component words.

Although there are many common idioms in English language, as a creative author, J. K. Rowling has ability to create the idioms that finally become characteristics of her story. In her writing, she involves the recreated idioms. With J. K. Rowling's creativity, some idioms in Harry Potter have different forms from those of the common English idioms. Rowling makes her own idioms using magical terminology. Basically those idioms are common ones, but, then, they are changed in such a way that they seem to be different form the original ones. For example, crying over spilled potion is derived from the common idiom crying over spilled milk. Since Potion is common liquid-thing in Harry Potter Magical World, Rowling puts it in her book and her reader can get the meaning of the idiom.

Idiom is a part of semantics as a part of linguistics. As one of the language components, the idioms are difficult to teach. This happened because this component of language is difficult to understand and learn because they do not mean what they literally state. Meanwhile, the idiom is the most frequently encountered in discourse appealing other 3 non-literal expressions (non-literal expressions: metaphor, simile, proverb, and idioms). For English as Second Language (ESL) and English as Foreign Language (EFL) student, idioms are problem.

The problems occur since the idiom is not an everyday language event for an English native speaker. This fact is not corroborate with the literature theory that novel is made to send the messages from the writer to the readers as many as possible. Idiom can lower the level of reader comprehension of the story. This problem is event more complicated for a non-native reader.

The complexity of the idiom is difficult to comprehend not only for the readers but also for the translators. There are so many translation errors in any languages in any country that has been translated the story.
Rowling is not making this easier by not only put many idioms in her story but also by modified them using different word in magical terminology. There must be a good reason for her in making this decision on her novel.

This research will systematically analyze the functions of idioms with magical terminology in building a make-believe magical world in J.K Rowling's Harry Potter and the Order of the Phoenix.

Using a popular novel that is full of linguistics feature such as Harry Potter will lead EFL/ESL students easier to learn about idioms. By analyzing idioms with magical terminology in J.K Rowling's Harry Potter and the Order of the Phoenix, hopefully the results of this research will also give an alternative way to teach English, especially idiom.

The paper describes the idioms with magical terminology in J. K. Rowling's Harry Potter and the Order of the Phoenix, analyzing the way they have been modified from real English idioms and how the idioms are related to the whole story. The analysis will be conducted for both the narration and the dialogues of the novel.

\section{Linguistics and Literature}

\section{Concept of Literature}

Literature is written works, especially those regarded as having artistic merit. It is world-wide or relating to a specific culture, or imaginative or creative writing, especially of recognized artistic value. Literature multiplies models of reality that operate on subjective and emotional levels, organizing categories of human experience of the contingent world (Swirsky, 2010, p.173).

In a more limited sense Guerin et al (2005, p.384) stated literature is a kind of art, usually written, that offers pleasure and illuminations. Literature addresses an audience in its own time and place, but because it makes interesting statement about human being and their universe, it addresses an audience in other times and other places as well. For literature is a part of the richness of human experience: it at once thrives on it, feeds it, and constitutes a significant part of it.

Fiction

James (1843-1916), one of a classic writer of English literature as it quoted by Augarde (1991:379) once said: 
The only reason for the existence of a novel is that it does attempt to represent life. (Partial Portraits - 1888 "Art of Fiction")

Fiction is the term used to describe works of the imagination. This is in contrast to nonfiction, which makes factual claims about reality. Fictional works-novels, pictures, stories, fairy tales, fables, films, comics, interactive fiction - may be partly based on factual occurrences but always contain some imaginary content. Fictions, in other words, acquire their dramatic character from readers who emote with imaginary people and, through them, calibrate their own emotions (Swirsky, 2010, p.175)

Furthermore Swirsky stated that living in the imagination is a peculiarly human condition. Readers experience the complex order of things in the narratives they read supercharged with emotions. Fictions, in other words, acquire their dramatic character from readers who emote with imaginary people and, through them, calibrate their own emotions. That is why, reading fictions, readers often feel that they ring true, even though it is not always easy to articulate this feeling in propositional form.

\section{Linguistics and the Novel}

The study of language and of literature was once united under the umbrella discipline of philology, and before that within the classical trivium of grammar, logic, and rhetoric. In the early years of the twentieth century, however, literary research and language studies began to bifurcate into separate, autonomous areas of inquiry (Logan, 2011, pp.487-490).

Over the years, novel has related to other forms of writing, such as journalism, advertising, documentary, history, etc. Novel has been analyzed from many perspectives. Mostly novel has been analyzed from the view of literature. However, there are some reasons why some research should approach the novel by way of linguistics.

Frameworks for linguistic inquiry can illuminate key aspects of the structure and interpretation of novels. Linguistic concepts can be used to explore referential dimensions of novelistic discourse, or the process by which novels evoke fictional worlds. Logan differentiated three fictional "scenes of talk" in his book The Encyclopedia of the Novel: (1) Deictic shift theory and narrative world-making, (2) Cogni- tive linguistics and narrative perspective, and (3) Corpus linguistics and mind-style.

Key questions in this area thus include: how do participants in fictional dialogues seek to convey more than they literally say, and how do novelists represent this process in ways that prompt reflection on the factors that can inhibit communication. For examples, how to differing background assumptions, contrasting cultural experiences, or asymmetric power relations? And how do novelists use characters' speech styles to explore interconnections between language practices and understandings of gender roles or social status, among other aspects of identity?

In the similar theory, Leech and Short (2007, p.121) wrote that the study of linguistics aspects in literature especially novel follow the principle that the language of literature cannot be understood without a proper appreciation of how ordinary language works. Everyday language is therefore the starting point, for the consideration of the way language is used to convey the 'mock reality' of fiction.

The Research Framework is Described in the Diagram:

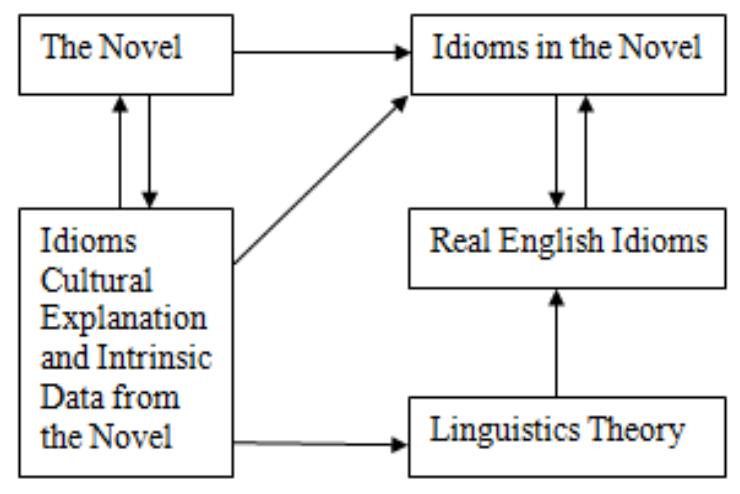

\section{FINDINGS AND DISCUSSION}

The idioms with magical terminology in Harry Potter and the order of the phoenix can be divined into few categories. In this thesis, those idioms are classified according to the source of the words that perform it. By classifying those idioms, they will be easier to be analyzed.

\section{Cultural idioms}

\section{Blood Traitor}

Blood traitor is a kind of term use by wizard refers to wizard who show some respect to muggle (human) or muggle-born wizard. There is discrimination in Wizarding world. Some wizards feel they have higher value than 
the other who was born from muggles. They believe, magic is only for pure wizard who was born from wizard parent. The wizards or witches that were born from muggle-parent called mudblood. In other side, pure-blood wizard/witch is they that were born from magic family. Blood traitor refers to this pure-blood, who disagrees with the discrimination.

The term blood traitor often used by pureblood wizard to humiliated another pure-blood who respects muggle and the muggle-born wizards. Rowling put this term to show the reader, if a character used it mean that he/she is an antagonist character.

Pure-blood

Pure-blood wizards/witches are they that were born from magic family. In other side, the wizards or witches that were born from muggleparent called mud-blood. This discrimination became an arguing topic in Wizarding community. Some wizards believe magic is only for pure-blood. But the other consider human-born - called as muggle or mudblood - can learn magic too, as long as they have talent.

Mudblood

Mudblood is the most often idiom occurred in the Harry Potter series. The reader of Harry Potter would know the meaning of the words without any explanation needed in the story. Mudblood is a term related to muggleborn wizard. It is an impolite idioms used by wizard to another wizard who was born from human or at least one human-parent. Mudblood mean literary as dirty blood. A very vicious term to use, but some wizards thought they are at higher class than other so could use the term.

Creature of Dirt

Creatures of dirt is still related with the blood status in Wizarding community. It is used by pure-blood mania to insult muggle-born wizard. The person who uses this idiom often is a person with antagonist character, such as Sirius Black's Mother. Mrs. Black was died years before. But her portrait was still hanging on Black Family House. In Magic World, picture is moving and acting as the real person. So Mrs. Black portrait has similar characters with her herself.

Blood status is something that is only found in Wizarding community. Wizard just likes muggle (human) having discrimination on their own race. Some wizards though they are better from other because they come from a family who is pure blood of wizard, none of them has married with muggle. From this idea that became an idealism (in negative) blood status became a culture in wizarding community. The terms like Mudblood, blood traitor, pure blood or creature of dirty comes from this civilization.

By using the terms in the novel, Rowling molded the idea that magic world really exist. This makes the reader pay more attention to her story.

\section{Historical Idioms}

\section{Even Bagman wouldn't have bet}

Bagman is a character is Harry Potter series. He was known as a person who like gamble very much. He would bet in anything, from final game in Quidditch World Cup, including a moment when he bet on Harry's life with a group of goblins.

Since Bagman know well as a crazegambler, Cornelius Fudge-The Ministry of Magic - use the phrase even Bagman wouldn't have bet... to express his unsure feeling about the story that Dumbledore had told him before.

Ludo Bagman once is an important character in the forth series of Harry Potter's, Harry Potter and the Goblet of Fire. Rowling believe her reader remembered the characteristic of Bagman as a gambler, so she uses the phrase even Bagman wouldn't have bet... in Harry Potter and the order of the Phoenix to make sense about the topic in the plot.

\section{Merlin's Beard}

The idiom is found in many pages of the novel. It is often use as exclamation of surprise, refers to famous magician in England, Merlin.

Peter Ackroyd (2002) in his book Albion: the Origins of the English Imagination described Merlin as a main character in Arthurian legend, the wizard who advised Arthur and his father, Uther Pendragon. There are accounts of Merlin's life in the work of Geoffrey of Monmouth and later writers. He helped Uther win Igraine, Arthur's mother, made the Round Table, cared for Arthur, and armed him with the sword Excalibur.

The term Merlin's Beard shows a humorous side of Rowling. It has no connection with any English term, but the reader of Harry Potter gets the meaning by simply. Merlin's Beard used to show a surprise feeling. 
In the Name of Merlin

In the name of Merlin is similar with in the name God/something. In A learner's Dictionary of English Idioms, In the name of somebody/something is representing somebody or something such as freedom or justice (often used as a reason for an action or request). Merlin as told above is a famous wizard who advised King Arthur and his father, Uther Pendragon in British legend. Merlin is a symbol of magic culture in England. By using Merlin in idiom that refers to someone who became a legend, Rowling trying to persuade her reader into a "fact" that magic does exist in England since thousand years ago, just like what she told in her novel.

Bagman and Merlin are two of famous magicians. Merlin believed as King Arthur's sorcerer and adviser in British legend. While Bagman is a character in the novel, he was like gambling maniac. Some idioms are used their names because they are famous. Merlin and Bagman became a kind of celebrities in wizarding community. Using the names of her own character in idioms is designed by Rowling in order to make the reader get closer to the story. Bagman took an important role in book four. While the idiom that used his name take place in book five. The reader who reads only the fifth book needs to read the previous books.

Muggle idioms

There are a lot of modified idioms in the novel. Rowling change the words in common idioms with magical terms. But she has a very creative inspiration with only modified the word that has similarity. For example: pigeon - pixie, truck - broom, milk - potion, cat - kneazle, money - galleon, horse - hippogriff.

Fell of the Back off the Broom

Fell off the back of a broom is similar with English idiom fell off the back of a lorry/truck. The idiom indicating that an item is of questionable origin and probably stolen.

"Broom" is transportation tool in magical world the novel. Wizards use it to traveling. Broom takes its rider fly from a place to another. It is also a tool of Wizard Famous Sport Quidditch.

"Lorry" is large vehicle for transporting goods etc. Similar with truck, that is mention as Lorry's synonym in Oxford dictionary.
Similar with English idiom fell off the back of a lorry/truck, fell off the back of a broom used in Harry Potter and the Order of the Phoenix novel to show that Mundungus - the character who left to see someone about a batch of cauldrons that fell off the back of a broom is in business with stolen cauldrons.

As will be hanged for a dragon as an egg

As well be hanged for a dragon as an egg is similar to English idiom might as well be hanged for a sheep as a lamb, mean that if one is going to be punished severely for a lesser offense, one might as well go further and commit a more serious offense.

The condition when Mrs. Figg uses the idiom was when Harry used his magic in muggle area. Underage wizard is abandoned to use magic outside the school. But as he already used it to protect him and Dudley from Dementors attack, Mrs. Figg told him to keep his wand out.

Harry broke the Reasonable Restriction of Underage Sorcery that forbids him to use wand out the school. But since he did it to protect himself and the enemies that threat him still around, he should keep his wand out to protect them. Mrs. Figg asked him to ignore the rule because he already disobeyed it before. She used the idiom might as well be hanged for a dragon as an egg to illustrated the condition right the moment.

Dragon is a creature that does exist in Wizarding World at Harry Potter novel. Dragon describe has egg to breed. Dragon is commonly mentioned in Harry Potter Series. By changing the words in English idiom might as well be hanged for a sheep as a lamb into As well be hanged for a dragon as an egg Rowling can send her message to her reader without any misunderstanding.

In this novel, might as well be hanged for a dragon as an egg is used to express Harry Potter conditions at the moment, when he already broke a rule and have to break it again.

\section{No Good Crying Over Spilled Potion}

The similarity of the idiom above with common idiom no good crying over spilled milk is undoubted. It is mean worrying, complaining, or feeling upset about damage, a mistake, or loss which cannot be put right has no value at all. Potion is common liquid thing in Harry Potter Magical World, Rowling put it in her book as the substitute of milk. Similar with milk, potion 
is use for healer or healthy drink. With using the idiom no good crying over spilled potion Rowling try to put potion as an existing liquid in her reader mind that even use as term of speech.

\section{The Cat's Among the Pixies Now}

The similar common idiom found on idioms dictionaries with idiom the cat's among the pixies is put the cat among the pigeons. "Put the cat among the pigeons" means arose strong feeling, especially of shock, dismay, or anger. Mrs. Figg use the idiom to show what she felt at the moment Harry Potter broke the Reasonable Restriction of Underage Sorcery. She felt shock because it was her task to keeping Harry not to do such that action, but she failed.

Pixy is magical creature. In her novel Rowling describe pixies as about eight inches high creatures. It has electric blue color, pointed paces and shrilling voices. They can fly to, just like pigeons.

Similarities between pixies and pigeon are they flying creature and tiny. By using pixies to modify pigeon, Rowling can give the clue to the reader to understand the idiom.

The cat's among the pixies, similar with English idiom put the cat among the pigeons, means arose strong feeling, especially of shock, dismay, or anger. Mrs. Figg used the idiom to Harry in addition to make him ignore what already happened, when Harry use magic in a restricted condition.

Time is Galleon

Time is Galleon is taken from a very common idiom time is money. Galleon is wizard's money. Many texts in Harry Potter novels told about galleon as a mean of purchasing.

When Fred said "Time is Galleon", he just had done an apparition. Apparition is kind of magic that allows the users to move from a place to another by materialize their bodies, so they can travel just in a second. Fred using "Time is Galleon" is to show that he did apparition to saving the time. If he uses usual way, walks from his room, he will spent more time than he did apparition. Rowling assumed that Galleon is a common word for her reader. By changing time is Money with Time is Galleon, she fervent the reader into the world of magic of her book.
Hold your Hippogriff

Hold your hippogriffs is used in comparison with English idiom Hold your horse, mean go or work more slowly; think about your action; often used as a request to wait. Hagrid used the idiom to ask Hermione be patience when he told his story met the giants in mountains. He felt disturbed when his story was cut in the middle by curious Hermione. So he told her to hold her Hippogriffs.

\section{Wasn't Room to Swing a Kneazle}

Wasn't room to swing a kneazle is similar with English idiom no room to swing a cat. In A learner's dictionary of English idioms, no room to swing a cat is an informal phrase to express a restricted or overcrowded space in which to live or work. Hagrid used the modified idiom to show how narrow the cave that he told in his story. Hagrid was told his story about a set of giants that were hiding from a murderous giant in a cave. Hagrid showed his agreement with Ron idea about the cave condition by used the idiom.

Kneazle is a magical creature. From Harrypotter.quaggabooks.co.uk, Kneazle expressed as a cat-like creature with an uncanny ability to detect suspicious character, thy can interbreed with cats. Similar definition showed in answers.com. In J.K. Rowling Harry Potter series, kneazles are magical creature close enough relative to cats to interbreed with them. A kneazle has large ears, spotted fur and a lionlike tail.

According to the definitions, Cat and Kneazle is very comparable animal. They only differentiated in a fact that cat is real animal while kneazle is a fiction.

\section{Losing a Knut and Finding a Galleon}

Knut and Galleon is wizard currency. Galleon's value is higher than Knut. Dumbledore used the expression like losing a knut and finding a galleon to express the condition when Fudge was going to Hogwarts intended to punish Harry Potter but instead he though he find the evidence of Dumbledore's disloyalty about him. Fudge was suspicious with Dumbledore for all time. He was afraid the headmaster of Hogwarts was on a trial of coup d'etat of his position as Ministry of Magic. As a result, when he found a parchment that he though was a confirmation of his suspicion, he was very surprised. Because in first, he was 
came to Hogwarts at the moment just only to catch Harry Potter.

Dumbledore knew what Fudge fell at the moment. With his humorous character Dumbledore teased Fudge by the idiom like losing a knut and finding a galleon, mean as getting something bigger or more valuable than expected.

\section{Old Bat and Old Hag}

Both terms are similar with old woman which mean fussy or timid person. Other sources give similarity idiom; Old Witch, with the same meaning. In the novel Mundungus used term old bat to refers to Mrs. Figg, an old single woman who usually babysat Harry Potter.

Rowling changed Old Witch/Old Woman into Old Bat or Old hag because her novel is already use term witch as a real thing. In spite of that, bat or hag is a common thing use for magic potion in Harry Potter world.

\section{Son of a Bludger's}

Son of a Bludger's is very similar with English rude idiom Son of a bitch. The idiom is refers to an impolite expression when a person insults another, or to express the extreme dislike of someone.
Bludger is a ball used in wizard sport, Quidditch

In this novel, the idiom son of a Bludger's was used by Mundungus who known as a crook person. Similar with son of a Bitch, son of a Bludger's is an impolite slang expression. It used to show a great anger with another person. Bludger, in this case, has comparable imply with bitch, that is a wild tricky thing or person. Rowling realize her novel is classifying for all age reader, including children. Using a vulgar word like Bitch will invite argument from parent. But to describe Mundungus character better, the using of impolite term has to do. By changing the term son of a bitch with son of a Bludger's, Rowling can avoid complaining from readers without losing her aim.

Miscellaneous/special Idiom (a) As transfigured a teabag, (b) Galloping Gargoyles, (c) Poisonous toadstools don't change their spots. The three of idioms above are classified as special idiom in this thesis. No similar English (muggle) idiom found comparing the three. But from the novel, those three terms have characteristics of idiom. The meaning of each word perform the terms are not the meaning of the term itself.

Table 1. The comparison between idioms with magical terminology and English Idioms

\begin{tabular}{|c|c|c|}
\hline Page - Line & Idioms with Magical Terminology & English Idioms \\
\hline $\mathrm{C} 2,20$ & fell of the back of the broom & fell of the back of the truck/lorry \\
\hline $\mathrm{C} 2,21$ & as transfigured a teabag & -- \\
\hline $\mathrm{C} 2,21$ & as will be hanged for a dragon as an egg & as will be hanged for a sheep as a lamb \\
\hline $\mathrm{C} 2,23$ & old bat & old witch \\
\hline $\mathrm{C} 2,24$ & crying over spilled potion & crying over spilled milk \\
\hline $\mathrm{C} 2,24$ & the cat's among the pixies now & the cat's among the pidgeons \\
\hline C4, 68 & time is galleon & time is money \\
\hline $\mathrm{C} 4,78-\mathrm{C} 6,103$ & blood traitor & -- \\
\hline \multicolumn{3}{|l|}{$\mathrm{C} 6,107-\mathrm{C} 6,108$} \\
\hline \multicolumn{3}{|l|}{$\mathrm{C} 6,110-\mathrm{C} 6,113$} \\
\hline C5, 86 & son of a bludger's & son of a bitch \\
\hline C6, 111. C6, 113 & pure-blood & -- \\
\hline $\mathrm{C} 8,146$ & even Bagman wouldn't have bet & -- \\
\hline $\mathrm{C} 7,134-\mathrm{C} 9,153$ & Merlin's beard & -- \\
\hline \multicolumn{3}{|l|}{$\mathrm{C} 20,421-\mathrm{C} 24,521$} \\
\hline \multicolumn{3}{|l|}{$\mathrm{C} 36,817$} \\
\hline $\mathrm{C} 10,181$ & creature of dirt & -- \\
\hline $\mathrm{C} 12,235$ & poisonous toadstools don't change their spots & -- \\
\hline $\mathrm{C} 13,272$ & old hag & old witch \\
\hline $\mathrm{C} 17,362$ & in the name of Merlin & in the name of God/something \\
\hline $\mathrm{C} 20,431$ & hold your hippogriff & hold your horse \\
\hline $\mathrm{C} 20,433$ & wasn't room to swing a kneazle & wasn't room to swing a cat \\
\hline $\mathrm{C} 27,612$ & galloping gargoyles & -- \\
\hline \multirow[t]{2}{*}{$\mathrm{C} 27,619$} & losing a knut and finding a galleon & -- \\
\hline & & -- \\
\hline
\end{tabular}


Table 2. The idioms with magical terminology in Harry Potter and the Order of the Phoenix and the meanings

\begin{tabular}{|c|c|c|}
\hline Page - Line & Idioms with Magical Terminology & The Meaning of the Idioms \\
\hline $\mathrm{C} 2,20$ & feel of the back off the broom & stolen things \\
\hline $\mathrm{C} 2,21$ & as transfigured a teabag & has no power to change the condition \\
\hline $\mathrm{C} 2,21$ & as will be hanged for a dragon as an egg & $\begin{array}{l}\text { doing another offense since a person } \\
\text { already did a lesser one }\end{array}$ \\
\hline $\mathrm{C} 2,23$ & old bat & fussy woman \\
\hline $\mathrm{C} 2,24$ & crying over spilled potion & $\begin{array}{l}\text { worrying or upset about a } \\
\text { damage/mistake has no value }\end{array}$ \\
\hline $\mathrm{C} 2,24$ & the cat's among the pixies now & arose strong feeling of shock \\
\hline C4, 68 & time is galleon & time must spend with a valuable act \\
\hline $\begin{array}{c}\mathrm{C} 4,78-\mathrm{C} 6,103- \\
\mathrm{C} 6,107-\mathrm{C} 6,108- \\
\mathrm{C} 6,110-\mathrm{C} 6,113\end{array}$ & blood traitor & wizard who respect muggles \\
\hline $\mathrm{C} 5,86$ & son of a bludger's & impolite expression to insult someone \\
\hline C6, 111 - C6, 113 & pure-blood & wizard who was born from wizard family \\
\hline $\mathrm{C} 8,146$ & even Bagman wouldn't have bet & a hardly believed announcement \\
\hline $\begin{array}{c}\mathrm{C} 7,134 \text { - C9, } 153 \text { - } \\
\mathrm{C} 20,421 \text { - C24, } 521 \text { - } \\
\mathrm{C} 36,817\end{array}$ & Merlin's beard & expression of surprise \\
\hline $\mathrm{C} 10,181$ & creature of dirt & impolite expression to insult someone \\
\hline $\mathrm{C} 12,235$ & $\begin{array}{l}\text { poisonous toadstools don't change their } \\
\text { spots }\end{array}$ & bad person never change \\
\hline $\mathrm{C} 13,272$ & old hag & expression refers to evil woman \\
\hline $\mathrm{C} 17,362$ & in the name of Merlin & represent the reason of an act \\
\hline $\mathrm{C} 20,431$ & hold your hippogriff & go or act more slowly \\
\hline $\mathrm{C} 20,433$ & wasn't room to swing a kneazle & express a restricted or overcrowded place \\
\hline $\mathrm{C} 27,612$ & galloping gargoyles & expression of surprise \\
\hline $\mathrm{C} 27,619$ & losing a knut and finding a galleon & miss an aim but get a better result \\
\hline & mudblood & $\begin{array}{l}\text { wizard who was born from muggle } \\
\text { family }\end{array}$ \\
\hline
\end{tabular}

\section{The Function of Idioms with Magical Termi- nology in Building the Story of the Novel as a Whole.}

Idioms with magical terminology in the novel Harry Potter and the Order of the Phoenix are found in conversation text. The idioms always came from the characters that were born in wizarding world. This style has function to bring the reader feeling as Harry Potter's feeling. As a person who never know magic or magic world, Harry Potter sometimes feel surprised to found many things new in his new environment. The reader will easier to feel what Harry feels if they read something that they know before but in another form, like idioms.

The idioms with magical terminology found in fourth book and many more in fifth book of the Harry Potter series. The terms that has been used in the idioms was explained in the previous books, such as galleon (first book), pixies (second book), or Hippogriffs (thirds book). No additional explanation for the idioms that used the terms. This will make the readers who only read the latest series will have to read the previous series to understand the meaning of the terms and the idioms.

Special for cultured idioms, Rowling used the idioms to build up the main plot of the whole novel series, discrimination. Some rude idioms such as mudblood or blood traitor support the idea of discrimination in wizarding community.

Literature is written works, especially those regarded as having artistic merit. It is world-wide or relating to a specific culture, or imaginative or creative writing, especially of recognized artistic value. Literature multiplies models of reality that operate on subjective and emotional levels, organizing categories of human experience of the contingent world (Swirsky, 2010, p.173).

In a more limited sense Guerin et al (2005, p.384) stated literature is a kind of art, usually written, that offers pleasure and illuminations. Literature addresses an audience in its own time and place, but because it makes interesting statement about human being and their universe, it addresses an audience in other 
times and other places as well. For literature is a part of the richness of human experience: it at once thrives on it, feeds it, and constitutes a significant part of it.

Rowling was trying to formulate a new language form (idiom) in her novel. By using the idioms that are "new" for her reader, she could make some effects on their mind. The effects are: (a) make a sense that the magical community does exist, they even has own language term including idiom; (b) make the funny feeling in the reader's mind, when they are connected the idiom with magical terminology with the familiar English idiom; (c) make curious feeling for the readers who read the book not by order; (d) make the sign of originality of her work.

\section{CONCLUSION}

There are 21 idioms with magical terminology found in Harry Potter and the Order of the Phoenix. The idioms can be divided into four categories; cultured idioms, historical idioms, muggle idioms and miscellaneous. In this thesis, those idioms are divided according to the source of the words that perform them.

The idioms have some functions in building the whole novel as a series of novels. First, idioms with magical terminology were use by Rowling to make her reader to believe that the world of magic does exist as it even has its own language (idioms). Second, those idioms occur without any explanation of the words that perform them like galleon or pixies. The magical terms have already clarified in prequels series. This mean readers who only read the latest series will have to read the previous series to understand the meaning of the terms and the idioms. Next, the idioms also have function in the plot about discrimination. Some rude idioms such as mudblood or blood traitor support the idea of discrimination in wizarding community.

Some idioms with magical terminology used in Harry Potter and the Order of the Phoenix are the modification of English idioms, but others are not.

\section{REFERENCES}

Ackroyd, P. (2004). Albion: the origins of the English imagination. New York: Anchor Books.
Ammer, C. (1997). The American heritage dictionary of idioms. Boston: Houghton Mifflin Company.

Augarde, T. (2010). Oxford dictionary of modern quotations. Oxford: Oxford University Press.

Clarke, Y. (2010). How idioms work resource book. Reading: Gamet Publishing Ltd.

Dixon, J.M. (1891). Dictionary of idiomatic English phrases. London: T. Nelson and Son.

Fields, J.W. (2007). Harry Potter, Benjamin Bloom, and the sociological imagination. International journal of teaching and learning in higher education, 19/2: 167-177.

Fromkin, V., Rodman, R., \& Hyams, N. (2011). An introduction to language ninth edition. Wadsworth: Cengage Learning.

Guerin, W.E., Labor, E., Morgan, L., et al (2005). A handbook of critical approaches to literature. Oxford: Oxford University Press.

Leech, G. \& Short, M. (2007). Style in fiction: a linguistic introduction to English fictional prose. Harlow: Pearson Education Limited.

Logan, P.M. (2011). The encyclopedia of the novel. West Sussex: Blackwell Publishing Ltd.

Magnuson, W. (2003). English idioms: sayings and slang. Alberta: Prairie House Books.

Rasekh, A.E. \& Shomoossi, N. (2008). The hidden curriculum in children's literature: the Hogwarts school of witchcraft and wizardry. Iranian Journal of Language Studies, 2/3: 359-380.

Rowling, J.K. (1997). Harry Potter and the sorcerer's stones. New York. Scholastics Press.

Rowling, J.K. (1998). Harry Potter and the chamber of secret. New York. Scholastics Press.

Rowling, J.K. (1999). Harry Potter and the prisoner of Azkaban. New York. Scholastics Press. 
Rowling, J.K. (2000). Harry Potter and the goblet of fire. New York. Scholastics Press.

Rowling, J.K. (2003). Harry Potter and the order of the phoenix. New York. Scholastics Press.

Rowling, J.K. (2005). Harry Potter and the halfblood prince. New York. Scholastics Press.

Rowling, J.K. (2007). Harry Potter and the deathly hallows. New York. Scholastics Press.
Rowling makes $£ 5$ every second. (3 October 2008). British Broadcasting Corporation. Retrieved on October 17, 2012 from http://news.bbc.co.uk/1/hi/entertainment/7649962.stm

Seliger, H.W. \& Shohamy, E. (1989). Second language research method. Oxford: Oxford University Press.

Siefring, J. (2004). Oxford dictionary of idioms. Oxford: Oxford University Press.

Swirsky, P. (2010). Literature, analytically speaking. Austin: University of Texas Press. 